УДК 552.42/.46/.48(470.324)

\title{
ГЕОЛОГИЯ ДОНСКОЙ СЕРИИ ДОКЕМБРИЯ ВОРОНЕЖСКОГО КРИСТАЛЛИЧЕСКОГО МАССИВА
}

\author{
Р. А. Терентьев \\ Воронежский государственный университет \\ Поступила в редакцию 16 мая 2018 г.
}

\begin{abstract}
Аннотация: в работе рассматривается донская серия Воронежского кристаллического массива, распространенная в Донском поясе среди батолитов и обширных мигматитовых полей гранитоидов павловского типа. Ранее исследователи описывали донскую серию/разрез/толщу как две контрастные породные ассоичации. Первая, гнейсо-гранитоидная (ГГА), представлена среднекрупнозернистыли «гнейсами» квари-полевошпатового состава. Вторая, стратифицированная ассоциация (СТА), состоит из чередования преимущественно мелкозернистых биотитовых ( 10 $\%)$, биотит-амфиболовых гнейсов и амфиболитов (более $50 \%$ ), мраморов и известковосиликатных пород (от 15 до 25 \%). Признаки термального воздействия на ксенолиты, микроструктурные особенности, свойственные изверженным породам, зональность и наличие примесных элементов в породообразующих минералах, идиоморфизм и осцилляциионная зональность ичирконов опровергают вероятность неплутонического происхождения ГГА. Постоянная пространственная связь ГГА с породами павловского комплекса, их сходство на макро и микроскопическом уровнях, а также состав породообразуюших минералов, характер их зональности и химизм валовых проб свидетельствуют об их когенетичности. Для ГГА характерны низкие ликвидусные температуры кристаллизации (840-900 $\left.{ }^{\circ} \mathrm{C}\right)$, относительно батолитов павловского комплекса (до $\left.1050{ }^{\circ} \mathrm{C}\right)$, но совпадаюшие давления при кристаллизации 2,1-3,8 kbar u 2,3-3,4 kbar, coответственно. ГГА не имеют отношения к донской серии/ассоџиаџии, а являются директивньми и контаминированными аналогами (инъекционными мигматитами) пород павловского комплекса в широком эндоконтактовом глубинном ореоле батолитов. СТА встречается на удалении от зон влияния батолитов или в виде крупных ксенолитов/прослоев среди ГГА и представляет собой основной объем донской серии. Все литотипы СТА характеризуются близкими размерами зерен, схожими бластическими микроструктурами, разнообразными текстурами от массивных до полосчатых, частым, иногда тонким чередованием контрастных типов пород, что подтверждает их принадлежность к стратифицированным объектам. Температуры и давления метаморфизма в СТА составили $784 \pm 13{ }^{\circ} \mathrm{C}$ и 3,8 $\pm 0,7 \mathrm{kbar}$. Среди протолитов СТА выделень: (1) известковощелочные высококалиевые железистые и высокомагнезиальные вулканогенные породы, (2) терригенные и карбонатные (известняки и мергели) осадки. Накопление толщ донской серии происходило в морском бассейне.
\end{abstract}

Ключевые слова: гнейсо-гранитоиды, гнейсы, амфиболиты, мраморы, известково-силикатные породы, стратиграфия, протолит

\section{GEOLOGY OF THE DON SERIES FROM THE EARLY PRECAMBRIAN VORONEZH CRYSTALLINE MASSIF}

\begin{abstract}
Don series from the early Precambrian Oboyan pluton-metamorphic complex of the Voronezh Crystalline Massif occurred in the Don belt among batholiths and extensive migmatite fields of Pavlovsk-type granitoids is considered. Previously, the researchers have been reported the Don series/ sequence/suite as two contrasting rock associations. The first, gneiss-granitoid association (GGA) is represented by medium-coarse-grained "gneisses" of quartz-feldspar composition. The second, stratified association (STA) consists of alternating mostly fine-grained biotite ( 10\%), biotite-amphibole gneisses and amphibolites (> 50\%), marbles and calc-silicate rocks (15-25\%). The features of thermal effect on xenoliths, microtextural attributes typical of igneous rocks, zoning and the presence of trace elements in rockforming minerals, idiomorphism and oscillatory zoning of zircon, contradict the probability of nonplutonic origin of the GGA. The regular spatial relation of GGA and Pavlovsk complex rocks, their similarity at
\end{abstract}


macro and microscopic scales, as well as the rock-forming mineral zoning and compositions, and the whole rock chemistry attest to their co-genetic properties. The GGA is characterized by low liquidus crystallization temperatures $\left(840-900{ }^{\circ} \mathrm{C}\right.$ ) relative to the Pavlovsky complex batholiths (up to $1050{ }^{\circ} \mathrm{C}$ ), though coincident emplacement and crystallization pressures of 2,1-3,8 kbar and 2,3-3,4 kbar are observed, respectively. The GGA is not related to the Don series/association, but is banded and contaminated counterparts (injected migmatites) of the Pavlovsk complex rocks from the vast endocontact zone from abyssal part of the batholiths. The STA is deposited at a distance from the batholith influence zone or occur as large xenoliths/interlayers among the GGA and represents the bulk of Don series. All STA lithotypes are characterized by close grain sizes, similar blastic microtextures, various structures from massive to banded, frequent alternation of rock types that supports their belonging to stratified objects. The temperatures and pressures of metamorphism of STA were defining $784 \pm 13{ }^{\circ} \mathrm{C}$ and 3,8 $\pm 0,7 \mathrm{kbar}$. The STA protoliths have been proposed: (1) calc-alkaline high-K ferroam and high-magnesian volcanogenic rocks, (2) terrigenous and carbonate (limestones and marls) sediments. The Don series sedimentation occurred in the marine basin.

Keywords: banded granitoid, gneiss, amphibolite, marble, calc-silicate rock, stratigraphy, protolith

\section{Введение}

Донская серия была выделена в объеме архейского обоянского плутоно-метаморфического комплекса ВКМ в одноименном поясе среди батолитов и обширных мигматитовых полей павловского гранитоидного комплекса.

Вещественный состав донской серии охарактеризован очень скудно, петрографические и геохимические исследования пород типовых разрезов отсутствуют (исключение - 3 образца неясной стратиграфической принадлежности в работе [1]). Возраст гнейсов донской серии является предметом острых дискуссий. (1) Слабо отрицательные значения $\varepsilon \mathrm{Nd}$ и сходство изотопных составов $\mathrm{Sr}-\mathrm{Nd}$ гнейсов донской серии и локализованных в них гранитоидов павловского комплекса позволили предположить генерацию гранитных расплавов и протолитов гнейсов за счет палеопротерозойского мантийного источника [1]. (2) Традиционно, полагаясь на петрографическое и петрохимическое сходство всех гнейсово-мигматитовых образований ВКМ с гранито-гнейсовыми образованиями других регионов мира, возраст донской серии отнесен к архейскому эону [2-5]. Вероятность архейского возраста метаморфических пород серии подтверждается находками древних ядер цирконов (около 2,6 млрд лет) в постколлизионных палеопротерозойских лейкогранитах Лискинского плутона [6] и U-

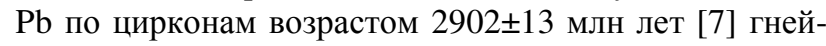
сов/гранитов из Шкурлатского карьера, вскрывающего Павловский батолит.

Обширные объемы гранитоидного магматизма были вовлечены в эволюцию Донского террейна ( 2040-2077 млн лет), а типы магматизма коррелировались с изменением тектонических обстановок $[1,8-$ 11]. По составу гранитоиды подразделены на два комплекса: (1) павловский, формировавшийся в две фазы: синскладчатую (кварцевые монцониты и кварцевые монцодиориты дифференцированые до гранодиоритов и монцогранитов порфировидных массивных в центре и равномернозернистых гнейсовидных в краевой зоне батолита) и постскладчатую (лейкограниты и пегматиты) [12-14], (2) лискинский лейкогра- нитный $[6,12,15]$. Генетическая связь между этими комплексами и вмещающими гнейсами донской серии слабо освещена и дискуссионна.

Цель статьи - восполнить пробелы по характеристике геологии, вещественного состава, петрохимии пород донской серии докембрия ВКМ. Обсуждаются вопросы литологического состава серии, идентификации и условий образования протолитов метаморфических пород.

\section{Исторический экскурс в петрографию и стратиграфию донской серии}

Гранитоиды и мигматиты в границах Донского террейна относили к павловскому комплексу, возраст которого считался палеопротерозойским [16]. Впервые донская серия упоминается в работе Епифанова [3], где она стратиграфически через перерыв и угловое несогласие помещена ниже курской железорудной серии и относится к наиболее древним раннедокембрийским образованиям региона. Петрография донской серии по данным этого автора не охарактеризована, однако, серия параллелизуется с днепровской (бугско-днепровской, древне-гнейсовой) серией Украинского щита. Опираясь на данные других авторов, Б. П. Епифанов [3] к донской серии достоверно относит только ксенолиты в гранитоидах по р. Дон (биотит-амфибол-олигоклазовые/андезиновые, амфиболовые и пироксен-магнетит-амфиболовые «роговики»), с большой степенью вероятности - полосчатые мигматиты (биотитовые и амфиболовые гнейсы, мигматизированные гранитом) в районе Коденцовской аномалии. Позднее у О. И. Египко [12] серия цитируется в ранге донской толщи михайловской серии (поздний архей), представленной реликтовыми пластообразными телами мигматизированных амфиболбиотитовых гнейсов и амфиболитов среди протерозойских гранитоидов павловского комплекса.

Опираясь на состав пород и характер наложенных процессов, выделялись [2]: (1) нижняя донская свита, сложенная реликтовыми телами среднезернистых биотит-амфиболовых плагиогнейсов, амфиболитами, магнетит-амфиболовыми породами, превращенными 
в средне-крупнозернистые биотит-роговообманковые граниты, гранодиориты, мигматиты и (2) верхняя донская свита, представленная реликтовыми телами амфиболитов, преобразованных в результате ультраметаморфизма в гранодиорито-гнейсы. Другими словами, авторы [2] считают все породы донской серии полностью или частично переработанными (мигматизированными и гранитизированными) более древними (позднеархейскими) относительно массивных гранитоидов павловского комплекса.

По данным В. Ю. Скрябина [15] в обрамлении Лискинского плутона донская серия состоит из монотонной толщи серых среднезернистых биотитамфиболовых гнейсов с прослоями амфиболитов и биотитовых плагиогнейсов. В гнейсах присутствуют угловатые обломки амфибол-полевошпатовых пород, которые аналогичны амфиболитам из прослоев. Иногда обломки имеют округлую форму и различно ориентированную сланцеватость, что позволило предположить груботерригенную природу гнейсов $[5,15]$.

Детальное петрографическое описание донской серии в районе Лискинского плутона осуществил И.П. Лебедев, однако эти материалы не опубликованы и сохранились лишь в архивных геологических отчетах. Тем не менее, по данным И.П. Лебедева в схеме стратиграфии и магматизма ВКМ [17] в объеме обоянской серии раннего архея выделен донской тип разреза (или донская ассоциация): гранодиорито-гнейсы биотит-амфиболовые, порфиробластические, монотонные; плагиогнейсы амфибол-биотитовые, реже биотитовые, мигматиты по перечисленным породам. Немного позднее в составе донской серии среди в различной степени гранитизированных амфиболовых гнейсов и биотитовых амфиболитов обнаружены прослои 0,8-1,2 м клиногумитсодержащих мраморов [18].

\section{Геологическая позиция}

Восточно-Сарматский (Волго-Донской) ороген слагает зону сочленения между Сарматским и ВолгоУральским сегментами Востоно-Европейского кратона (рис. 1) и является результатом орогенеза имевшего место 2,2-2,05 млрд лет назад [1, 8, 19-21]. Эта провинция состоит из нескольких террейнов (Донской, Лосевский и Воронцовский, рис. 1), разделенных крупными региональными разломами и зонами дробления. В Донском террейне, метаморфизм

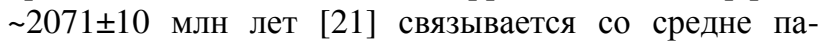
леопротерозойским орогенезом, а возраст протолита согласно Sm-Nd данным составляет 2562-2670 млн лет [1]. Роговообманково-биотитовые граниты (РБГ) пространственно связаны с гнейсами/амфиболитами Донского террейна. РГБ комплекс назывемый павловским преобладает на севере и юге террейна в виде крупных (1500-2000 км²) плутонов (например Павловский и Хохольско-Репьевский батолиты). Этот магматизм рассматривается нами как постколлизионный, так как он датирован (2076,8 33,1 млн лет; [8]) более поздним временем, чем коллизионное тектонометаморфическое событие (около 2115 млн лет; [22]) в регионе. В Донском поясе также представлены тела белогорьевского комплекса с предполагаемым предшественниками архейским возрастом. Считается, что комплекс метаморфизован и представлен горнблендитами, габбро-амфиболитами и пироксенитами (рис. 2), которые слагают линзовидные, изометричные тела площадью 0,5-2 км² не установленной мощности.

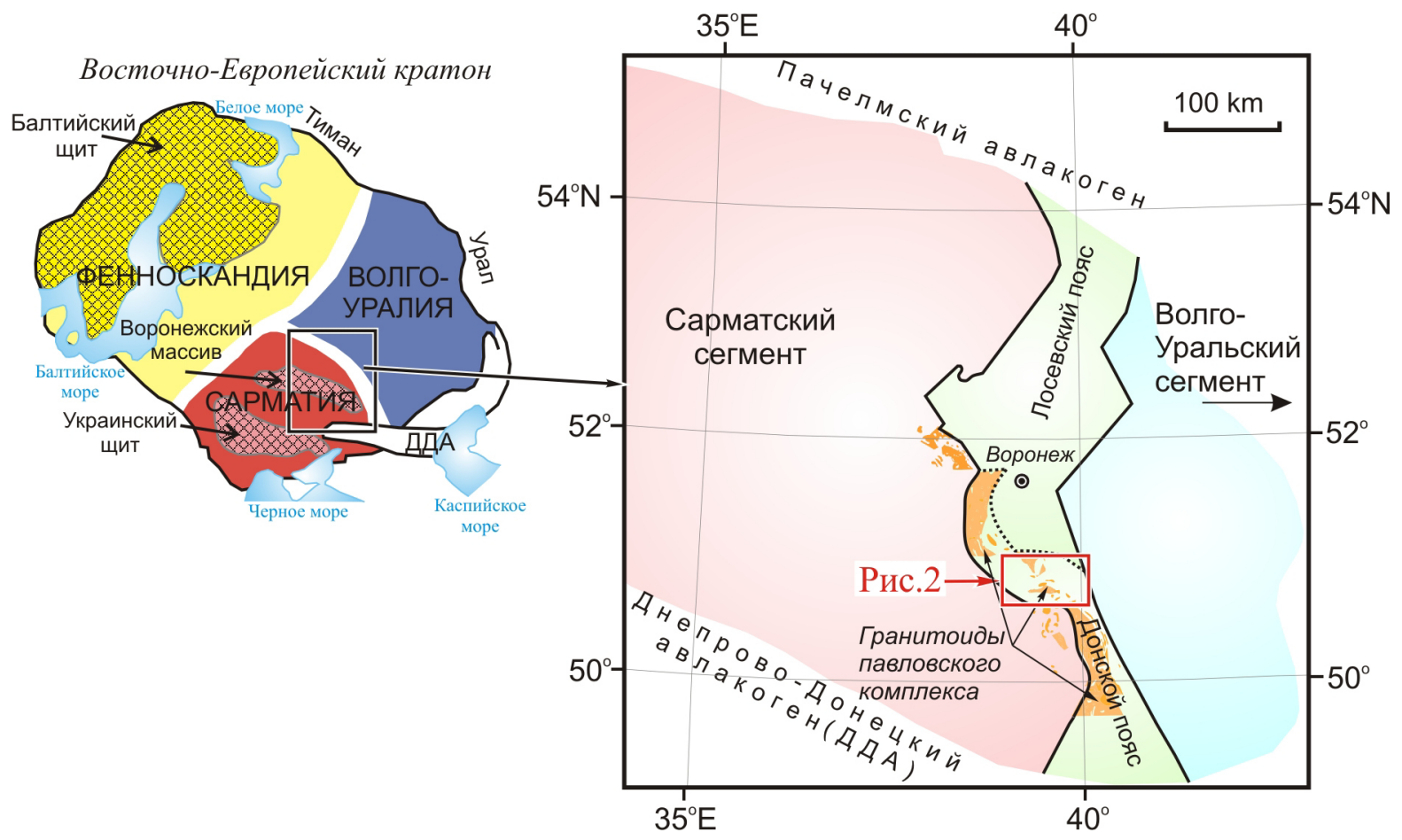

Puc. 1. Схема расположения ВКМ в пределах Восточно-Европейского кратона. 


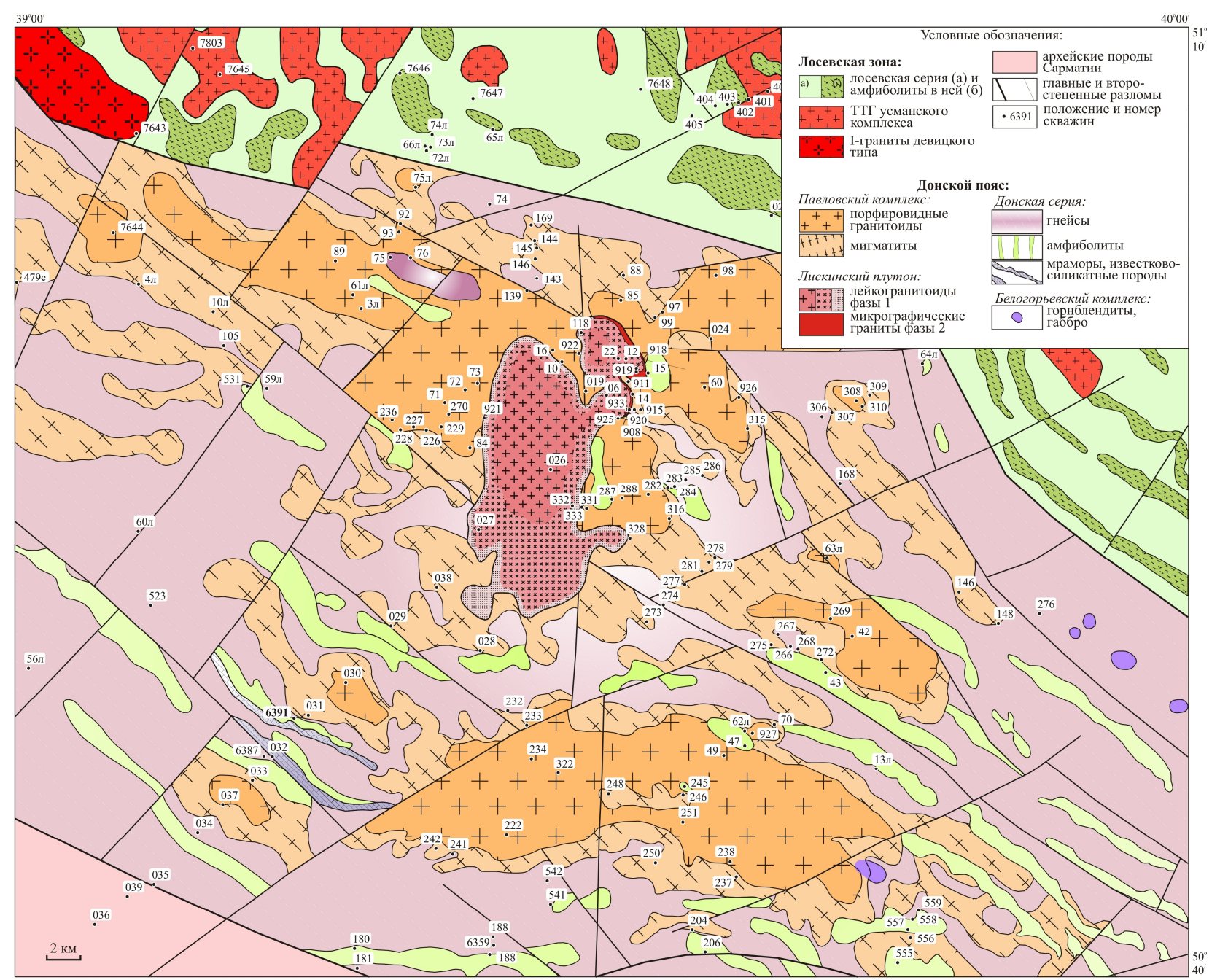

Puc. 2. Геологическая схема стратотипической местности донской серии в районе Лискинского плутона.

\section{Материал и методы исследования}

Так как все предшествующие исследователи отмечали значительное термальное воздействие гранитоидов павловского комплекса и/или анатексиса на породы донской серии, важной задачей был поиск скважины, которая вскрывает глубокий наиболее полный по литологическому составу и наименее затронутый магматизмом разрез донской серии. Единственная скважина 6391 глубиной 445 м, вскрывающая наиболее пестрый по петрографическому составу разрез, обнаружена в районе Лискинского плутона в центральной части Донского пояса. Местоположение скважины, керн которой использован для детальных петрографических и петрохимических исследований, показано на рис. 2. Привлечены также петрографические данные из стратотипической местности по образцам собственной коллекции и любезно предоставленым И.П. Лебедевым (ВГУ) из скважин к-8, к-84, к-85, к-98, к-247, к-270, к-284, к315, к-333, к-343, к-345, к-393, к-915, к-918, к-920, к931 и др. Геологическая основа (рис. 2) построена по данным картировочного и специализированного бурения с привлечением гравимаг нитных карт масшта- ба 1:200 000 и крупнее.

Петрографическое описание горных пород, взаимоотношения минералов, их кристаллооптические свойства изучались при помощи прямого оптического поляризационного микроскопа OLYMPUS BX51-P. Образцы пород для силикатного анализа были истерты в порошок с крупностью зерен 50 мкм. Затем методом квартования отобрана навеска массой 1 г. Далее образцы были высушены при температуре $110^{\circ}$ С до состояния воздушно-сухой пробы, затем - прокалены до постоянной массы при температуре $1000^{\circ}$ С. Подготовка излучателей для анализа породообразующих элементов выполнена путем плавления 0,5 г порошка пробы, 2 г тетрабората лития и 2 г метабората лития в муфельной печи с последующим отливом стеклообразного диска. Химический состав проб определен на рентгенофлуоресцентном спектрометре S8 Tiger (Bruker AXS GmbH, Германия). Результаты исследований получены на оборудовании ЦКПНО ВГУ (аналитик Е.Х. Кориш). При калибровке спектрометра и для контроля качества измерений были использованы государственные стандартные образцы химического состава горных пород - СГ-4 (ГСО 
№10135-2012), ССЛ-1 (ГСО №3191-85), СТ СЭВ 2300-80, СТ СЭВ 2296-80, ОСО №300-00. Точность анализа составляла 1-2 \% отн. \% для элементов с концентрациями выше 1-5 мас. \% и до 5 отн. \% для элементов с концентрацией ниже 0,5 мас. \%.

Локальные анализы минералов выполнены на электронном микроскопе Jeol 6380LW с системой количественного энергодисперсионного анализа «Inca» (ВГУ). Условия анализа: ускоряющее напряжение 20 кв, ток зонда 1,2 mA, время набора спектра 90 сек, диаметр пучка 1-3 мкм. ZAF коррекция при расчете содержания окислов и оценка точности проводились с помощью комплекта программ математического обеспечения системы. Точность анализа систематически контролировалась по эталонным образцам природных и синтетических минералов.

\section{Результаты исследования}

Как видно из предыдущего обзора работ предшественников, все типы пород донской серии повсеместно, но в разной степени, подвержены региональному анатексису и/или инъецированию мигматита- ми/гранитами. Поэтому автор предлагает разделить описание пород донской серии на те, которые минимально затронуты гранитоидным плутонизмом или мигматизацией (по сути, это разрез скважины 6391 и крупные ксенолиты/обломки амфиболитов и гнейсов среди средне-крупнозернистых кварц-полевошпатовых пород (рис. 3)) и те, которые в значительной степени переработаны гранитной магмой и/или мигмой (наиболее широко распространенные средне-крупнозернистые породы, также относимые предшественниками к донской серии).

Район исследований расположен в Лискинском районе на западной стороне центральной части ВСО (рис. 2). Эта область ранее считалась стратотипической для донской ассоциации в объеме обоянского плутоно-метаморфического комплекса [17]. В районе исследований широко распространены интрузии павловского комплекса, которые окружены обширными полями мигматитов. В центре участка (рис. 2, 3) расположен Лискинский лейкогранитный плутон, который отчетливо прорывают как магнезиальные гранитоиды павловского комплекса, так и гнейсово-

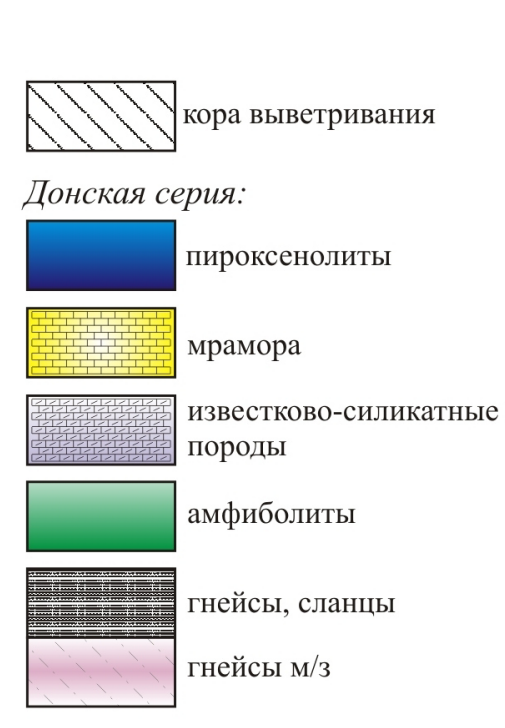

Лискинский комплекс:

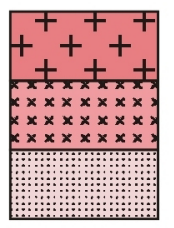

граниты центральной

промежуточной и

мелкозернистой фаций

Павловский комплекс:
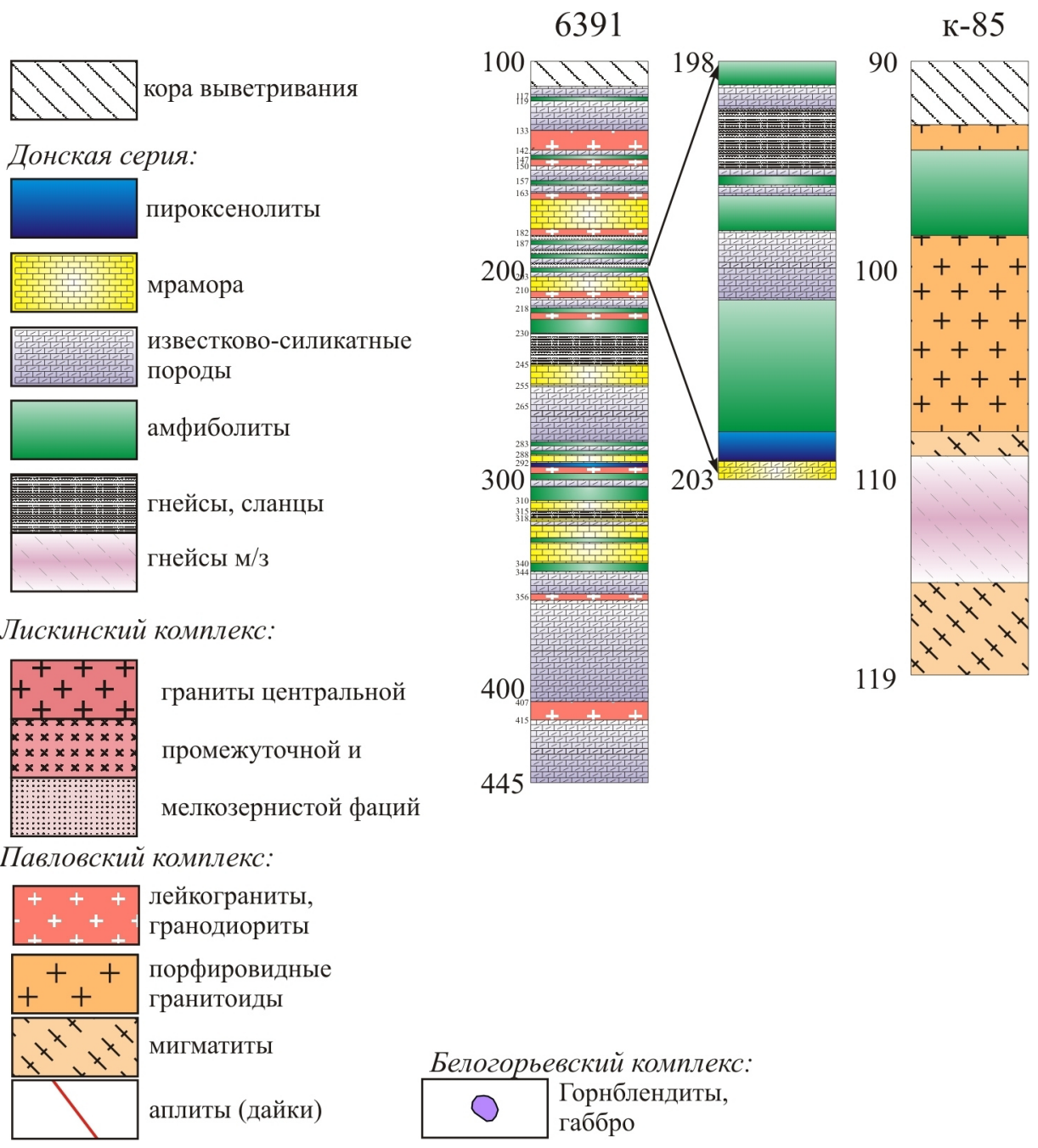

\begin{tabular}{|c|} 
Белогорьевский комплекс: \\
\hline$\quad \begin{array}{l}\text { Горнблендиты, } \\
\text { габбро }\end{array}$
\end{tabular}
К-920

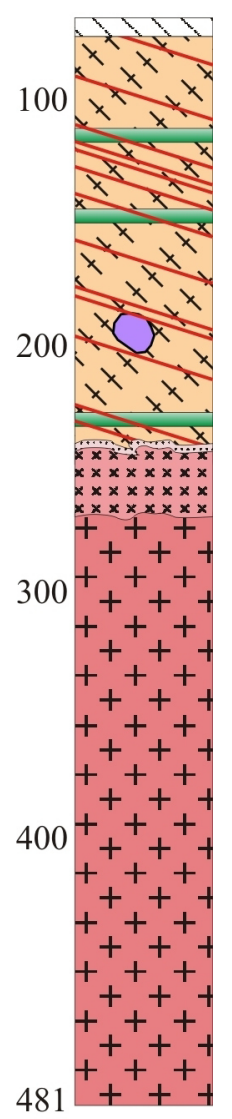

Рис. 3. Геологические разрезы скважин 6391 (донская серия), к-85 (гранитоиды павловского комплекса со скиалитами амфиболитов и гнейсов) и к-920 (контактовая зона Лискинского плутона и гранитоидов павловского комплекса). 
-амфиболитовые толщи донской серии. Рвущий контакт Лискинского плутона установлен в разрезе скважины к-920 (рис. 3). В лейкогранитах плутона обнаружены ксенолиты павловских гранитоидов и амфиболитов донской серии.

\section{Геология донской серии: в связи и вне связи с гранитами и мигматитами В связи с гранитами и мигматитами павловского комплекса}

Гнейсовые поля донской серии на карте (рис. 2) показаны условно и представлены чередованием мелкозернистых амфиболитов/гнейсов и средне-крупнозернистых иногда порфировидных директивных кварцполевошпатовых пород (гнейсо-гранитоидов ${ }^{*}$ ), которые предшественниками относились к донской серии, по существу являются продолжением мигматитовых полей. Ориентировка магнитных аномалий свидетельствует о северо-западном простирании складчатых структур вмещающих пород и/или полосчатости мигматитовых полей и директивности гранитоидов. В стратотипической местности образования, относимые к донской серии, представлены достаточно однотипной и монотонной толщей среднезернистых амфибол-биотитовых гнейсов (?) (гнейсо-гранитоидов) с прослоями биотитовых плагиогнейсов и амфиболитов с мелкозернистой структурой, которые больше напоминают породы в областях с минимальным развитием плутонических пород павловского комплекса. Считается, что гнейсогранитоиды составляют преобладающую часть разреза донской серии [17]. В описываемых породах повсеместно присутствуют угловатые и изометричные включения амфибол-плагиоклазовых пород, по текстурно-структурным особенностям и минеральному составу аналогичные амфиболитам из самостоятельных прослоев (рис. 4). Эти включения имеют как четкие границы, так и постепенные переходы к среднезернистым гнейсо-гранитоидам с примесью меланократовой (амфиболитовой) составляющей (рис. 4, вверху слева). В полосчатых включениях образуются послойные обособления кварц-полевошпатового гранитоподобного состава или появляются мелкие рассеянные вдоль плоскостей полосчатости кристаллы микроклина. В амфиболитовых включениях на контакте наблюдается биотитизация амфибола, мелкие спорадические выделения микроклина. В сланцеватых амфиболитах или в трещинах массивных разновидностей встречаются прожилки и линзы аналогичные по составу вмещающим гнейсо-гранитоидам, но более лейкократового состава.

\section{Вне связи с гранитами и мигматитами} павловского комплекса

Дислоцированные метаморфические породы Донского террейна, включая многочисленные ксенолиты

\footnotetext{
* Здесь и далее буду называть эти породы гнейсо-гранитоидами, чтобы подчеркнуть их директивность, модальный состав и микроструктурные особенности
}

в гранитоидных батолитах, обладают похожими текстурными, деформационными, метаморфическими и структурными характеристиками, которые отличаются от окружающих средне-крупнозернистых кварцполевошпатовых пород среди мигматитовых полей павловского комплекса (рис. 4).

Группа незатронутых гранитизацией/мигматизацией разрезов расположена в юго-западной части изучаемой площади (скважины 6391, 6387, 032). Обобщенный разрез в основном состоит из амфиболитов, гнейсов, мраморов и метаморфизованных известковосиликатных пород. Все эти породы испытали метаморфизм амфиболитовой фации, и расчеты Р-T значений показывают, что метаморфизм имел место при температурах 500-700 ${ }^{\circ} \mathrm{C}$ и давлениях 5 кбар [18]. В донскую серию внедрялись протерозойские дайки мелкозернистых и пегматоидных лейкогранитов мощностью менее 10 м, которые не оказывают заметного термального влияния на вмещающие породы. Дайки секут сланцеватость и полосчатость вмещающих пород под большим углом. Полевые наблюдения показывают, что гнейсы и амфиболиты чаще встречаются в средних и верхних частях разреза среди более мощной толщи мраморов и известково-силикатных пород. Мощность прослоев гнейсов и амфиболитов варьирует от нескольких сантиметров до первых метров. За пределами разреза по скажине 6391 амфиболиты и меланократовые гнейсы образуют прослои от 1 см до 4,2 м или слагают мощные горизонты видимой мощностью до 45 м. Амфиболиты и меланократовые гнейсы в маломощных прослоях, как правило, сланцеватые, а в центральных частях наиболее мощных тел характеризуются массивной текстурой. Мраморы и известково-силикатые породы представляют собой один литотип, так как первые отличаются от вторых лишь количеством примеси силикатной составляющей. Карбонатные породы характеризуются разнообразными текстурами - от массивных до полосчатых и пятнистых (рис. 4). Пятнистая текстура обусловлена вкраплениями/включениями силикатного состава и кварца, так же как и полосчатость - чередованием тонких полос обогащенных или обедненных силикатными минералами и кварцем.

\section{Петрография и минералогия}

Гнейсо-гранитоиды средне-крупнозернистые. Они характеризуются серой, розовато-серой и розовотемно-серой окраской, микроструктурными особенностями аналогичными павловским гранитоидам (рис. 5). По модальному составу [23] породы классифицируются как кварцевые монцодиориты, кварцевые монцониты, монцограниты и гранодиориты. Главные минералы представлены плагиоклазом, калишпатом, кварцем, амфиболом (редко с клинопироксеновым ядром), биотитом. Сумма мафических минералов достигает 27,2 \%, причем от наиболее меланократовых к лейократовым разновидностям падает содержание мафических минералов (Amp=1,7-8,5 \%, Bt 12,2-18,7 $\%)$. Вместе с уменьшением темноцветных минералов 

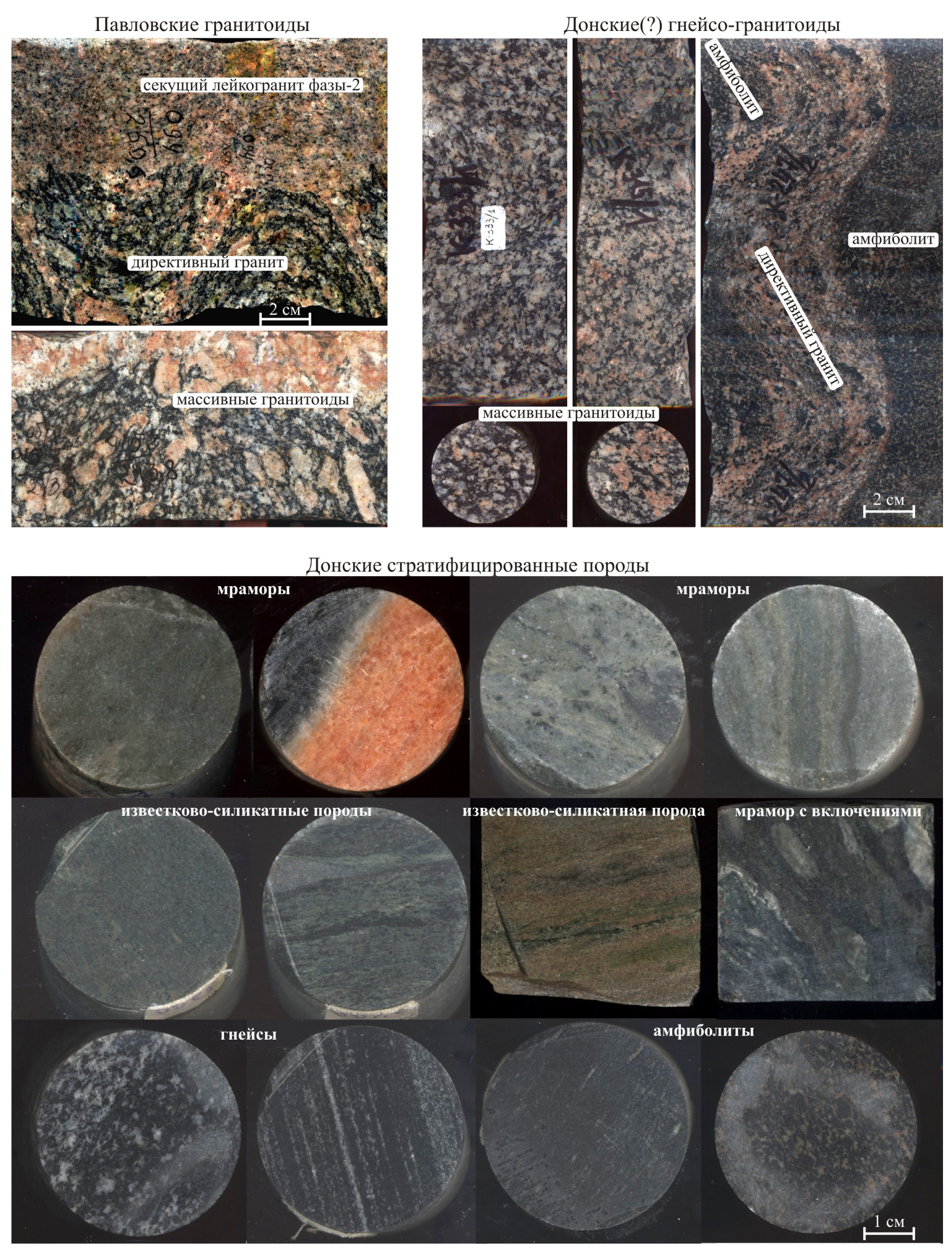

Puc. 4. Фотографии керна. Вверху слева типичные представители гранитоидов павловского комплекса (массивные порфировидные гранитоиды из центра батолитов и директивные равномернозернистые гранитоиды из краевых зон). Вверху справа так называемые гранодиорито-гнейсы, в том числе порфиробластовые, которые отнесены предшественниками к донской серии. Внизу типичные представители гнейсов, амфиболитов, известково-силикатных пород и мраморов донской серии. 

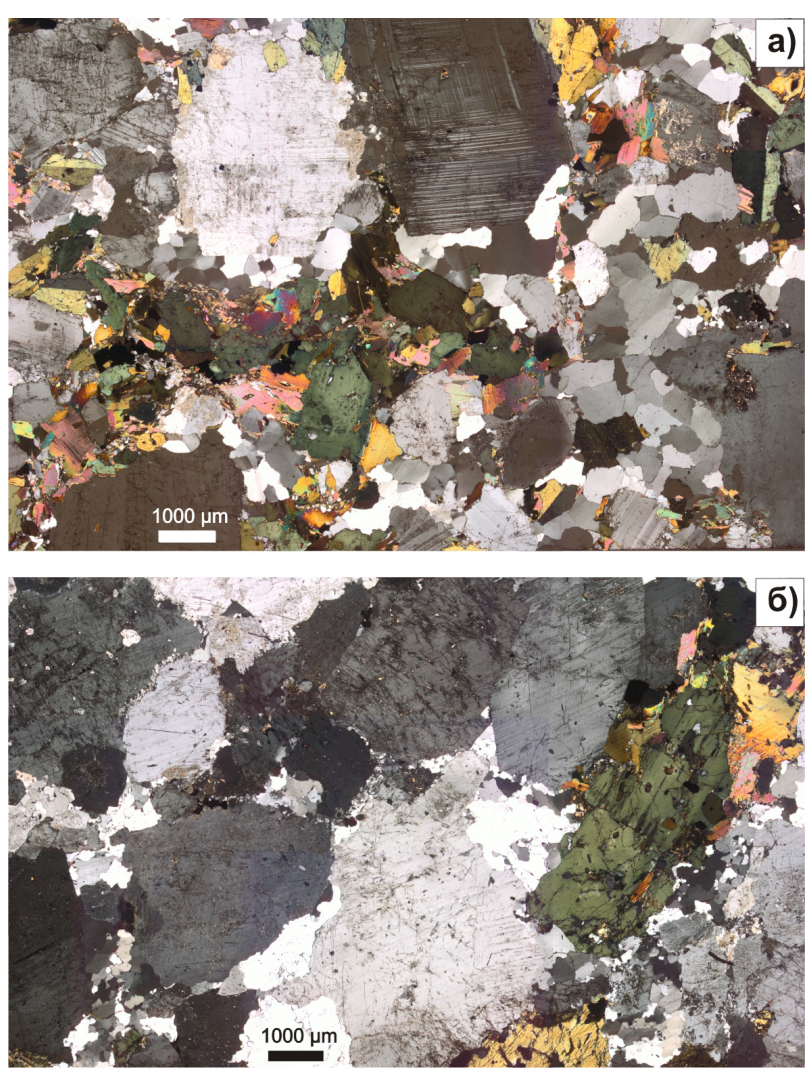

Puc. 5. Фотографии гнейсо-гранита, относимого предшественниками к донской серии ( $a$ ) и типичного гранитоида павловского комплекса (б).

в породах растет содержание кварца (11-21 \%) и уменьшается плагиоклаза (48-64 \%). Акцессорные минералы представлены магнетитом, титанитом, апатитом, цирконом, эпидотом, титаномагнетитом и сульфидами.

Плагиоклаз субгедральный до ангедрального (рис. 6 д, е), местами в виде изометричных включений в калишпате. Его состав соотвествует олигоклазу (An=24 $\%$ в среднем). Зональность проявлена в порфировидных кристаллах в виде постепенного уменьшения анортитового минала от центра к краю (An от 32 до 17 \%). Плагиоклазы основной массы характеризуются кислым составом с An 9-17 \%. Для полевых шпатов характерна постоянная примесь $\mathrm{FeO}$ до $1 \%$. Калишпат - это чаще всего микроклин, отчетливо пертитовый, содержащий включения преобладающего плагиоклаза, а также подчиненных амфибола, биотита, кварца, циркона, апатита и магнетита. На границе калишпатовых кристаллов наблюдаются мирмекиты. Кварц залегает как неправильной формы скопления изометричных зерен в основной массе или ксеноморфные кристаллы.

Амфибол проявляется как ангедральные пойкилитовые зерна или как суб- до эвгедральных кристаллы, во всех случаях содержащие включения магнетита, плагиоклаза, апатита, титанита. Большинство амфиболов имеют $(\mathrm{Ca})_{\mathrm{B}}>1,5$ и $(\mathrm{Na}+\mathrm{K})_{\mathrm{A}}=0,2-0,7$ и относятся к эденитам, магнезиогастингситам и магнезиальной роговой обманке (рис. 7), часто с примесью хрома. Катионное отношение $\mathrm{Mg \#}\left(\mathrm{Mg} /\left(\mathrm{Mg}+\mathrm{Fe}^{2+}\right)\right)$ амфиболов ва- рьирует от 0,49 до 0,68 и в среднем постепенно уменьшается при уменьшении $\mathrm{SiO}_{2}$ в породе. В большинстве разновидностей пород амфиболы незональные по составу. Содержание $\mathrm{Al}_{2} \mathrm{O}_{3}$ варьирует между 6,9 и 8,6 мас.\%. Биотит, как правило, ангедральный характеризуется Мg\# слабо варьирующим от 0,49 до 0,58, примесью хрома. Циркон и апатит участками бывают многочисленны, формируют идиоморфные кристаллы, которые включены почти во всех породообразующих минералах. Преобладающая Fe-Ti-оксидная фаза идиоморфный магнетит с примесями $\mathrm{Ti}, \mathrm{V}, \mathrm{Al}, \mathrm{Mg}$ и др. элементов. Редко встречается ксеноморфный ильменит. Титанит представлен двумя генерациями: одна идиоморфная конвертообразная и вторая ксеноморфная в виде кайм по магнетиту и титаниту первой генерации.

Гнейсы биотитовые. Они слагают незначительные по распространенности прослои. От биотитамфиболовых гнейсов отличаются полосчатой текстурой и лейкократовым составом, который обусловил их серые и светло-серые цвета. Биотитовые гнейсы характеризуются разной зернистостью от тонкой до мелкой, лепидобластовой структурой. Породы сложены, кроме кварц-полевошпатовой части, зеленовато-бурым биотитом, иногда присутствуют графит, силлиманит. Среди полевых шпатов повсеместно преобладает олигоклаз. Часто встречаются крупные угловатые зерна кварца или кварц-полевошпатовых срастаний.

Гнейсы биотит-амфиболовые и амфиболитыл. Эти мелкозернистые породы рассматриваются совместно, так как отличаются незначительно по содержанию кварц-полевошпатовой составляющей. Породы темнозеленоватые, темно-серые до черных (рис. 4). Амфиболиты и гнейсы имеют гипидиобластовую мелкозернистую структуру. Амфиболиты состоят из плагиоклаза (27-65 \%) и амфибола (20-70 \%) с примесью биотита $(0-18 \%)$ и кварца. В гнейсах значительную роль играет плагиоклаз (42-68\%), биотит (7-23\%), а количество амфибола (1-17 \%) уменьшается параллельно с увеличением содержаний кварца (11-26 \%). В обоих типах пород присутствует одинаковый набор акцессорных минералов: титанит, магнетит, апатит, циркон и сульфиды. В отличие от средне-крупнозернистых гнейсогранитоидов в мелкозернистых метаморфических породах магнетит и титанит практически лишены примесных элементов. Большинство амфиболов имеют $(\mathrm{Ca})_{\mathrm{B}}>1,5$ и $(\mathrm{Na}+\mathrm{K})_{\mathrm{A}}<0,5$ и относятся к магнезиальным и железистым роговым обманкам, реже к эденитам, без примеси хрома. Катионное отношение $\mathrm{Mg \#}(\mathrm{Mg} /(\mathrm{Mg}+$ $\left.\mathrm{Fe}^{2+}\right)$ ) амфиболов варьирует от 0,34 в гнейсах до 0,51 в амфиболитах (рис. 7). Содержание $\mathrm{Al}_{2} \mathrm{O}_{3}$ варьирует между 7,4 и 10,8 мас.\%. Плагиоклаз образует гранобластовый агрегат (рис. 6б, в). Его состав и в гнейсах, и в амфиболитах соответствует олигоклазу-андезину $\left(\mathrm{An}_{\mathrm{cp}}=31 \%\right)$. Для полевых шпатов не характерны примеси $\mathrm{FeO}$ и других фемических оксидов. Лепидобласты биотита характеризуется Mg\# слабо варьирующей от 0,46 до 0,54, без примеси хрома. Первично метаморфические калиевые полевые шпаты не обнаружены. 

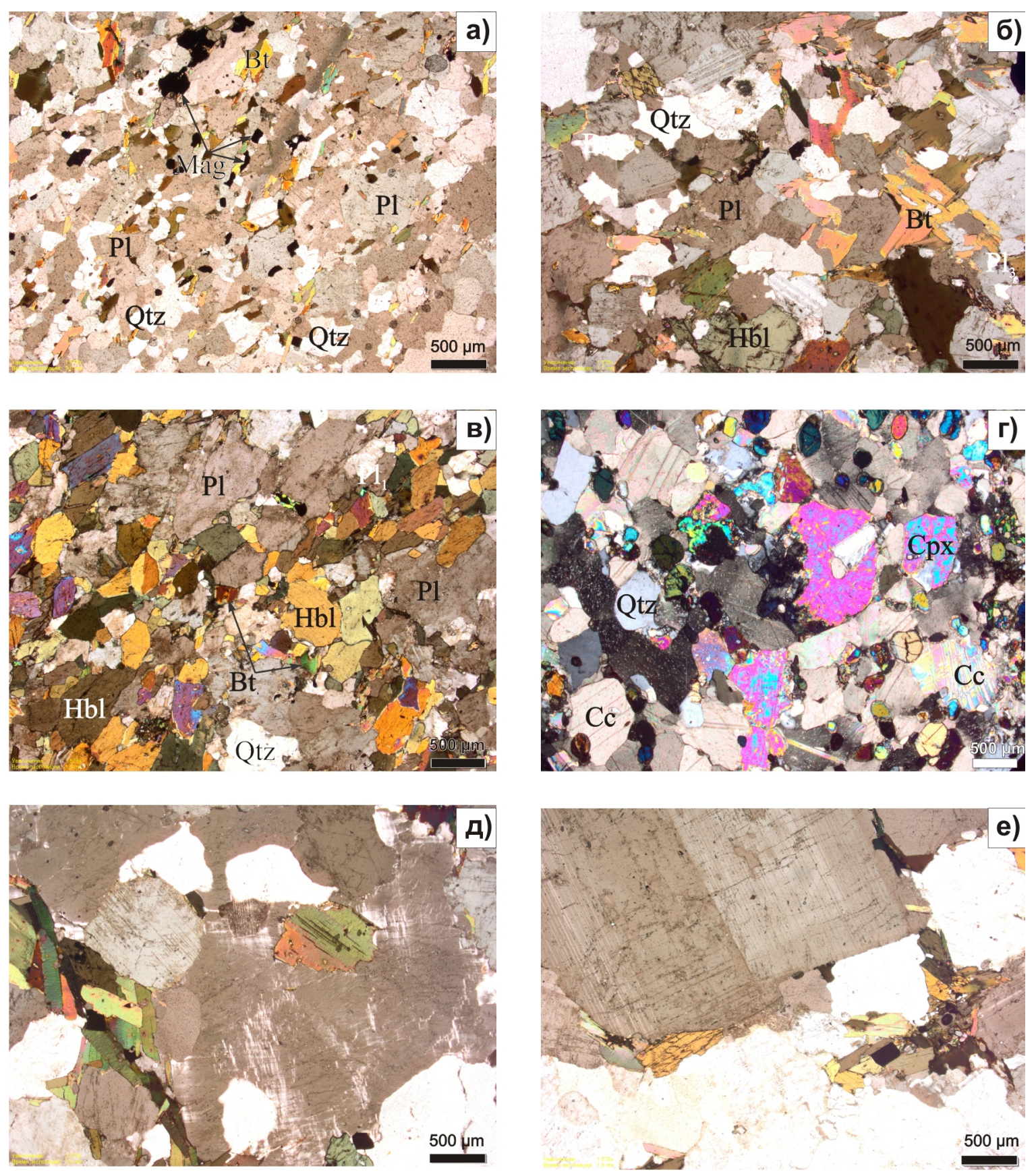

Рис. 6. Фотографии шлифов стратифицированных пород донской серии: а - биотитовый гнейс, б - биотит-амфиболовый гнейс, в - амфиболит, г - пироксеновый мрамор, д, е - для сравнения показаны более крупнозернистые гнейсо-гранитоиды, относимые предшественниками к донской серии.

Мраморы и известково-силикатные породы. Обогащенные карбонатом породы бледно-зеленые, серые, светло-серые или желтые до оранжевых, обычно содержат многочисленные включения или тонкие слойки, сложенные силикатными минералами и кварцем. Кальцитовые мраморы встречаются в виде серых и зеленоватых слоев, чередующихся с амфиболитами/гнейсами и известково-силикатными породами (рис. 3). Их мощность колеблется от нескольких сантиметров до, в исключительных случаях, 20 метров (интервалы в средней части разреза 6391). Ткань обогащенных карбонатом пород часто характеризуется широкой до тонкой полосчатостью, благодаря чему даже в одном образце керна можно наблюдать мелкие складки. На границе мраморов и амфиболитов в редких случаях наблюдаются маломощные (до 35 см) слойки пироксенолитов (вероятно, скарноиды). Панидиобастовая карбонатная часть пород (рис. 6г) состоит из кальцита с примесями клинопироксена, плагиоклаза, титанита, редких клиногумита и оливина. Полосы, линзы, включения состоят из изометричных зерен клинопироксена, кварца, полевых шпатов, амфибола, эпидота и сульфидов. В известковосиликатных породах или силикатных прослоях 


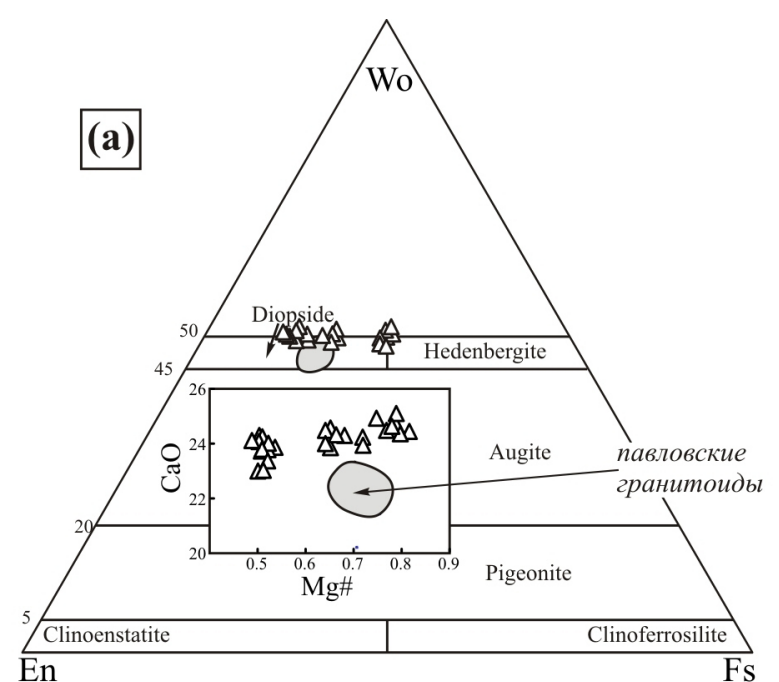

$(\mathbf{0})$

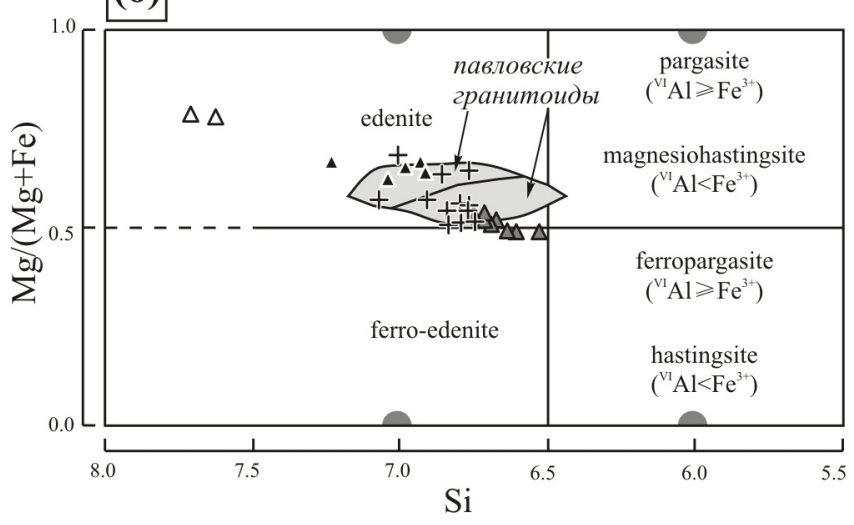

$\Delta \quad$ мраморы, известково-силикатные породы

$\Delta \quad$ гнейсы биотит-амфиболовые

- амфиболиты
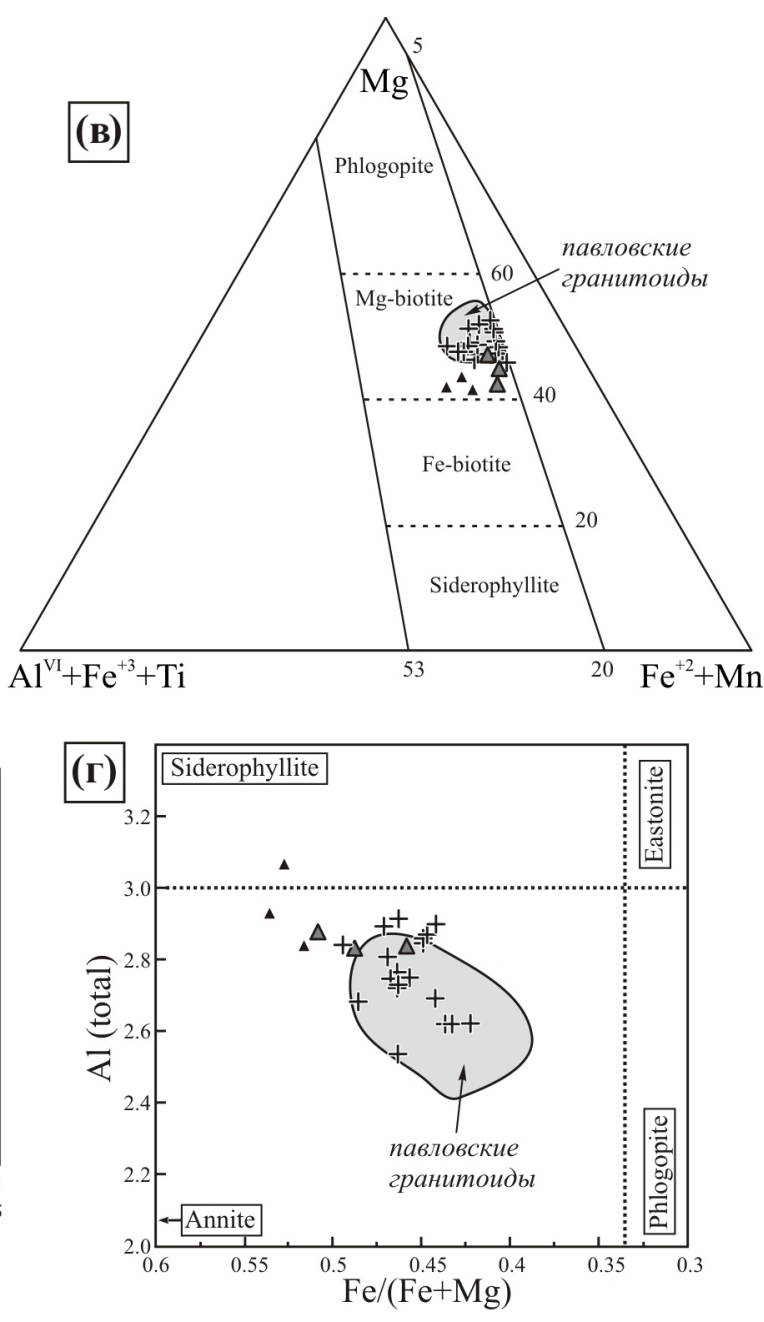

$+\quad$ гнейсо-гранитоиды, относимые

предшественниками к донской серии

Puc. 7. Составы а - пироксенов; б - амфиболов; в-г - биотитов из гнейсо-гранитоидной и стратифицированной ассоциаций донской серии на классификационных диаграммах по [24-27]. Поля составов минералов из гранитоидов павловского комплекса даны по [14].

часто наблюдаются ксеноморфные ойкобласты клинопироксена и/или амфибола. Заметных реакционных зон на границе карбонатных и силикатных агрегатов не обнаружено. Контакты между известково-силикатными породами и мраморами постепенные, а контакты с амфиболитами/гнейсами отчетливые прямые или извилистые, особенно в сильно деформированных породах, где известково-силикатные полосы очень сложной формы и переменной толщины (до нескольких сантиметров).

Карбонаты в изученных образцах представлены почти чистыми кальцитами, иногда с примесями магния или железа. Клинопироксены соответствуют диопсидам и волластонитам, составы которых сосредоточены вдоль линии, разделяющей эти миналы (рис. 8). Они практически лишены примесей, например $\mathrm{Cr}$, Ti, Na, что наряду с высоким содержанием $\mathrm{CaO}$ отличает их от клинопироксенов из гранитоидов павловского комплекса (рис. 7). Гранобластовые плагиоклазы мраморов представлены битовнитом (An = 72-75\%), а в известково-силикатных породах - ан- дезином. Кварц, чаще всего, образует ксеноморфные зерна, соразмерные основной ткани пород или значительно превышающие средний размер кристаллов. Крупные ксеноморфные кристаллы кварца, наряду с ксеноморфным относительно кислым плагиоклазом (альбит-олигоклаз), - свидетельство терригенной примеси в описываемых породах.

\section{Петрохимия}

Гнейсо-гранитоиды. Проанализированные образцы характеризуются широкими вариациями содержаний кремнезема от 59,2 до 71,1 мас.\%. Гнейсогранитоиды являются магнезиальными, высококалиевыми, известково-щелочными до щелочных (рис. $8)$, метаглиноземистыми [A/CNK $\left(\mathrm{Al}_{2} \mathrm{O}_{3} / \mathrm{CaO}+\mathrm{Na}_{2} \mathrm{O}+\right.$ $\left.\left.\mathrm{K}_{2} \mathrm{O}\right)<1\right]$ породами. Тренды составов гнейсо-гранитоидов демонстрируют уменьшение $\mathrm{Al}_{2} \mathrm{O}_{3}, \mathrm{TiO}_{2}$, $\mathrm{Fe}_{2} \mathrm{O}_{3} \mathrm{t}, \mathrm{MgO}, \mathrm{CaO}, \mathrm{P}_{2} \mathrm{O}_{5}$ и увеличение $\mathrm{K}_{2} \mathrm{O}$ с увеличением $\mathrm{SiO}_{2}$ и чаще всего совпадают с полями составов плутонических пород павловского комплекса. 

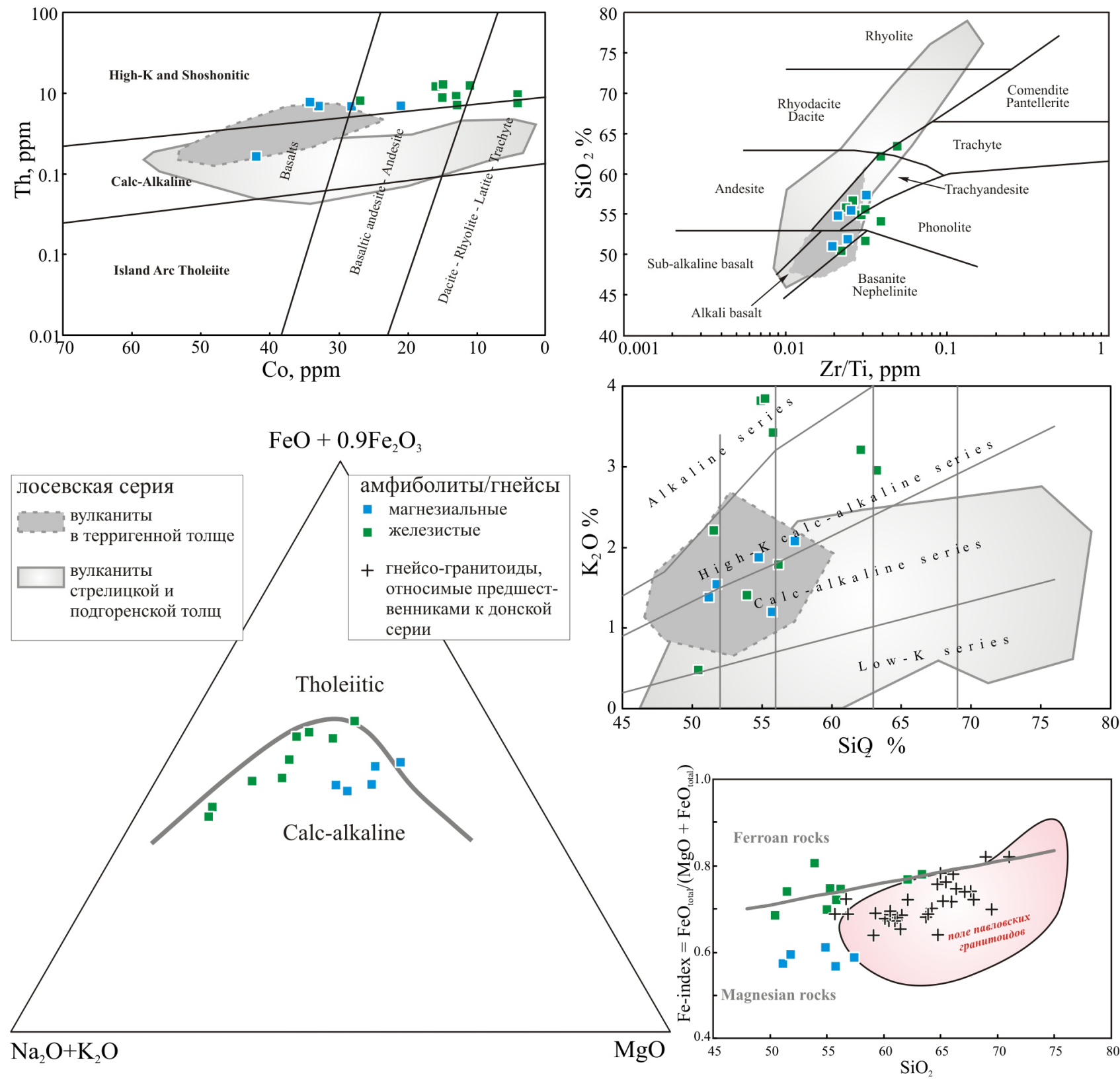

Puc. 8. Диаграммы для классификации пород Донского пояса: (а) $\mathrm{Co}-\mathrm{Th}$ [28], (б) $\mathrm{Ti} / \mathrm{Zr}-\mathrm{SiO}_{2}$ [29], (в) $\mathrm{K}_{2} \mathrm{O}-\mathrm{SiO}_{2}$ [30], (г) $\mathrm{AFM} \mathrm{[31]} \mathrm{и} \mathrm{(д)} \mathrm{FeO}^{*}-\mathrm{SiO}_{2}$ [32]. Поля составов лосевской серии даны по [20].

Гнейсы биотит-амфиболовые и амфиболитьл. Амфиболиты/гнейсы донской серии демонстрируют известково-щелочной химизм с вариациями кремнезема от 50,5 до 63,3 мас.\%. Некоторые амфиболиты обогащены $\mathrm{MgO}(5,3-7,9$ мас.\%), что типично для высоко-магнезиальных андезитов и базальтов. Точки составов амфиболитов и гнейсов образуют единые тренды на диаграммах петрогенных оксидов. Они классифицируются как высококалиевые и щелочные, что дополнительно подтверждается классификациями, основанными на соотношении некогерентных элементов (рис. 8).

Мраморы и известково-силикатные породы. Среди обогащенных карбонатом пород чистые мраморы отсутствуют, поэтому наряду с высокими содержани- ями $\mathrm{CaO}(38-49 \%)$ и потерь при прокаливании (18-28 \%) в них обнаруживаются высокие концентрации кремнезема (до $31 \%$ ) и других оксидов: $\mathrm{Al}_{2} \mathrm{O}_{3}(3,3-4,5$ $\%), \mathrm{Fe}_{2} \mathrm{O}_{3}(1,8-7,6 \%), \mathrm{MgO}(0,6-2,6 \%)$. Известковосиликатные породы по сравнению с мраморами содержат меньше $\mathrm{CaO}(7,9-36,8 \%)$ и потерь при прокаливании (1-17 \%) более высокие концентрации кремнезема (до $57 \%$ ) и других оксидов: $\mathrm{Al}_{2} \mathrm{O}_{3}(3,9-$ $15,4 \%$ ), $\mathrm{Fe}_{2} \mathrm{O}_{3}(5,1-13,3 \%), \mathrm{MgO}$ (до 4,2 \%).

\section{Дискуссия}

Анализ выводов предшественников и результаты данного исследования свидетельствуют о существовании двух контрастных объектов при описании в опубликованных и архивных источниках так называ- 
емой донской серии/разреза/ассоциации/толщи. Первый представлен средне-крупнозернистыми гнейсами гранитоидного состава, тесно ассоциирующими с плутоническими породами и мигматитами павловского комплекса, которые в статье названы гнейсогранитоидами. И, второй, состоящий из чередования преимущественно мелкозернистых метаморфических пород: биотитовых гнейсов, биотит-амфиболовых гнейсов и амфиболитов, мраморов и известковосиликатных пород. Во втором случае меньше всего возникает сомнений в том, что эта ассоциация пород является первично стратифицированной и имеет прямое отношение к донской серии как объекту стратиграфии. В связи с этим возникают вопросы о реальном вещественном составе донской серии и вероятных протолитах обоих породных ассоциаций.

\section{О литологии донской серии}

Гнейсо-гранитоидная ассоциаџия. Две основные версии о генезисе ассоциации обсуждались предшественниками: (1) вулкано-терригенная до груботерригенной первичная природа метаморфической толщи $[5,15]$ и (2) ультраметаморфический генезис гранитогнейсов (мигматитов), образованных по зеленокаменным породам [2, 33]. Во втором варианте гнейсогранитоиды считаются более древними (позднеархейскими) относительно протерозойских павловских батолитов.

Признаки термального воздействия на включения амфиболитов/гнейсов (биотитизация амфибола, проникновение кварц-полевошпатовой части по трещинам и вдоль директивности пород из включений), микроструктурные особенности (мирмекиты, различная идиоморфность минеральных фаз), зональность породообразующих минералов, наличие примесных элементов в составе плагиоклаза $(\mathrm{FeO})$, амфибола и биотита $\left(\mathrm{Cr}_{2} \mathrm{O}_{3}, \mathrm{~V}\right)$, магнетита (Ti, V, Al, Mg), идиоморфизм и осцилляционная зональность цирконов характерны для магматических пород. Это в значительной мере опровергает вероятность неплутонического происхождения рассматриваемых гнейсогранитоидов. Против ультраметаморфизма свидетельствуют простые масс-балансовые рассчеты. Так, даже при высокой степени выплавления аллохтонной мигмы, образовались бы в два-три раза превышающие по объему слои меланократовых слоев мафитового состава. Однако, наоборот, все исследователи отмечают, в локальных разрезах и по площади, преобладание гнейсо-гранитоидной части над всеми остальными типами пород, например, амфиболитами. Все эти линии доказательств предлагают по-новому взглянуть на природу включений в гнейсо-гранитоидах. Это не обломки амфиболитов/гнейсов, а ксенолиты, испытавшие термальное воздействие и частичную перекристаллизацию и новообразования. Более того, постоянная ассоциация гнейсо-гранитоидов с плутоническими массивными и директивными гранитоидами, сходство на макро (рис. 4) и микроскопическом (рис. 5 и 6) уровнях с гранитоидами павловского комплекса свидетельствуют о их когенетичности. Описываемые гнейсо-гранитоиды и плутонические породы павловского комплекса схожи и по составу породообразующих минералов (плагиоклазы, амфиболы, биотиты) (рис. 7), и по характеру их зональности, и по химизму (рис. 8). В данной работе не показаны некоторые петрохимические отклонения гнейсо-гранитоидов, относимых ранее к донской ассоциации от поля павловских гранитоидов. Однако эти отклонения закономерны, так как гнейсо-гранитоиды развиты на периферии батолитов, содержат значительное количество ксенолитов вмещающих пород и, соответственно, в значительной степени контаминированы. Геолого-структурная позиция гнейсо-гранитоидов обусловила низкие ликвидусные температуры кристаллизации (840$900^{\circ} \mathrm{C}$, по геотермометру апатитового насыщения [34], относительно ядерных частей батолитов (от $1050{ }^{\circ} \mathrm{C}$, [14]). Тем не менее, давления при кристаллизации, оцененные с помощью Al-в-амфиболе геобарометра, откалиброванного по экспериментальным данным $[35,36]$, совпадают в гнейсо-гранитоидах $(2,1-3,8$ kbar) и породах павловского комплекса (2,3-3,4 kbar, [14]). Главный вывод по данной части обсуждения о том, что гнейсо-гранитоиды, ранее относимые к донской серии/ассоциации [17], являются директивными и контаминированными аналогами пород павловского комплекса в широком эндоконтактовом глубинном ореоле батолитов. Поэтому изотопно-геохимические данные, полученные в работе [1], для пород павловского комплекса и «гнейсов» донской серии идентичны. Так как часто гнейсо-гранитоиды чередуются с вмещающими мелкозернистыми амфиболитами/гнейсами, образуя широкую макрополосчатость и проникая по трещинам и вдоль сланцеватости/полосчатости ксенолитов, то их можно считать инъекционными мигматитами.

Стратифиџированная ассоџиаџия. Так как гнейсо-гранитоиды исключаются из объема донской серии, то в ее составе остаются амфиболиты/гнейсы, мраморы и известково-силикатные породы. Все литотипы характеризуются близкими размерами зерен, схожими бластическими микроструктурами. Для них установлены разнообразные текстуры от массивных до полосчатых, частое, иногда тонкое чередование контрастных типов пород, что подтверждает их принадлежность к стратифицированным объектам. Стерильность породообразующих минералов в отношении примесных элементов, например, $\mathrm{Fe}$ в полевых шпатах, $\mathrm{Cr}$ в биотитах и амфиболах, $\mathrm{Cr}, \mathrm{Ti}, \mathrm{V}, \mathrm{Mg}$ в магнетитах, $\mathrm{Ti}, \mathrm{Cr}, \mathrm{Na}$ в клинопироксенах, также доказывают метаморфическое происхождение первично стратифицированных пород донской серии. Температуры и давления оцененные по амфибол-плагиоклазовому парагенезису в амфиболитах/гнейсах составили $784 \pm 13^{\circ} \mathrm{C}$ и $3,8 \pm 0,7$ кбар. Наблюдения в рамках данного исследования и сообщения предшественников (например, $[2,3,13,15])$ позволяют примерно оценить количественные соотношения различных литотипов в объеме донской серии. Ясно, что преоб- 
ладающими типами являются амфиболиты и амфибол-биотитовые гнейсы (более 50 \% объема серии), которые образуют непрерывный ряд по текстурноструктурным признакам, количественно-минеральному составу и общим трендам на петрохимических диаграммах. Часть разреза (возможно, около $10 \%$ ) представлена прослоями биотитовых гнейсов, количество которых может быть недооценено из-за визуального сходства с гнейсо-гранитоидами. Кроме того, предшественниками отмечены находки амфиболовых магнетитовых кварцитов и пироксен-магнетитамфиболовых «роговиков» (кристаллических сланцев). Важную роль в составе донской серии играют мраморы и известково-силикатные породы, доля которых в локальных разрезах составляет около $50 \%$ (например, скважина 6391). Тем не менее, находки обширных полей карбонатом-обогащенных пород в пределах стратотипической местности редки, что может быть связано с: (1) локальным прерывистым распространением, (2) поглощением огромными массами гранитоидных магм и/или (3) нахождением на более глубоких уровнях, не вскрытых скважинами. Так как скважин, вскрывающих толщи донской серии не так много, как казалось ранее, то оценки по объему мраморов и известково-силикатных пород находятся в интервале от 15 до $25 \%$.

\section{Протолиты донской серии}

Мафитовый до среднего химизм, в целом однородный минеральный состав, единые тренды на петрохимических диаграммах амфиболитов и биотитамфиболовых гнейсов позволяют отнести их к исходно вулканогенным и вулканогенно-осадочным образованиям. Геохимические особенности, например высокие содержания $\mathrm{Ni}, \mathrm{Cr}, \mathrm{Co}$, низкая глиноземистость, высокая магнезиальность отдельных образцов также свидетельствуют в пользу вулканогенной природы амфиболитов и связанных с ними гнейсов. Разные текстуры от массивных до полосчатых, вариации мощностей от тонких прослоев до 45 м подтверждают присутствие среди амфиболитов/гнейсов исходных пирокластов и вулкано-терригенных пород. Наоборот, полосчатость, неравномерная зернистость с присутствием крупных ксеногенных обломков, малая мощность тел биотитовых гнейсов свидетельствуют в пользу терригенной природы с возможной примесью вулканогенного материала. А накопление толщ донской серии в морском бассейне подтверждается прослоями мраморов и известково-силикатных пород (протолиты - известняки и мергели).

Вулканогенная часть разреза. Исходя из того, что метабазиты метаморфизованы в условиях, отвечающих, как минимум, амфиболитовой фации метаморфизма, их протолиты имеют отношение к доколлизионным событиям. Метаморфизм приведший к полной потере реликтовых структур в амфиболитах/гнейсах, отличает их от большей части амфиболитов лосевской серии. Установить исходно эффузивную или пирокластическую/вулканогенно-осадочную природу амфи- болитов крайне сложно, однако маломощные прослои сланцеватых амфиболитов/гнейсов больше типичны для пирокластики и/или вулканогенно-осадочных пород. Мощные (более 1-2 м) слои, могут представлять собой эффузивные аналоги, что косвенно подтверждается находками пироксенолитов (скарноидов, как доказательство горячего контакта) на границе амфиболитов и мраморов. Все вулканиты относятся к известково-щелочной высококалиевой серии, однако разделяются на железистую и высоко-магнезиальную ветви (рис. 8). По химизму вулканиты донской серии в первом приближении близки известково-щелочным породам из терригенной толщи лосевской серии, однако отличаются более высокими содержаниями калия, тория (рис. 8).

Осадочная часть разреза. Полосчатые биотитовые гнейсы с неравномернозернистой структурой и ксеногенными включениями интерпретируются как первично осадочные породы, возможно, с примесью вулканогенного материала. Обогащенные карбонатом породы по химическому составу соответствуют известнякам и мергелям. Силикатная примесь в них представлена терригенным детритом (обломки кварца и полевых шпатов) и, с большой долей вероятности, имеет вулканогенно-осадочное происхождение. Последнее подтверждается частым переслаиванием карбонатных пород с метабазитами, микропрослоями и включениями силикатного состава (амфибол, пироксен).

\section{Выводы}

1. Ранее исследователи описывали донскую серию/разрез/толщу как две контрастные породные ассоциации. Первая, гнейсо-гранитоидная ассоциация, представлена средне-крупнозернистыми «гнейсами» кварц-полевошпатового состава, тесно ассоциирующими с плутоническими породами и мигматитами павловского комплекса. Вторая, стратифицированная ассоциация, состоит из чередования преимущественно мелкозернистых биотитовых, биотит-амфиболовых гнейсов и амфиболитов, мраморов и известковосиликатных пород.

2. Признаки термального воздействия на ксенолиты, микроструктурные особенности, свойственные изверженным породам, зональность породообразующих минералов, наличие примесных элементов в составе плагиоклаза $(\mathrm{FeO})$, амфибола и биотита $\left(\mathrm{Cr}_{2} \mathrm{O}_{3}\right.$, $\mathrm{V})$, магнетита ( $\mathrm{Ti}, \mathrm{V}, \mathrm{Al}, \mathrm{Mg})$, идиоморфизм и осциляционная зональность цирконов опровергают вероятность неплутонического происхождения гнейсогранитоидов. Устойчивая ассоциация гнейсо-гранитоидов с породами павловского комплекса, их сходство на макро и микроскопическом уровнях, а также по составу породообразующих минералов, характеру их зональности и химизму валовых проб, свидетельствуют об их когенетичности.

3. Геолого-структурная позиция гнейсо-гранитоидов обусловила низкие ликвидусные температуры кристаллизации $\left(840-900{ }^{\circ} \mathrm{C}\right)$, относительно батолитов 
павловского комплекса (от $1050{ }^{\circ} \mathrm{C}$ ). Однако давления при кристаллизации в гнейсо-гранитоидах (2,1-3,8 kbar) и породах павловского комплекса (2,3-3,4 kbar) совпадают. Таким образом, гнейсо-гранитоиды не имеют отношения к донской серии/ассоциации, а являются директивными и контаминированными аналогами (инъекционными мигматитами) пород павловского комплекса в широком эндоконтактовом глубинном ореоле батолитов.

4. Стратифицированная ассоциация встречается на удалении от зон влияния батолитов или в виде крупных ксенолитов/прослоев среди гнейсо-гранитоидов и представляет собой основной объем донской серии. Все литотипы характеризуются близкими размерами зерен, схожими бластическими микроструктурами, разнообразными текстурами от массивных до полосчатых, частым, иногда тонким чередованием контрастных типов пород, что подтверждает их принадлежность к стратифицированным объектам. Средние температуры и давления метаморфизма оцененные по амфибол-плагиоклазовому парагенезису в амфиболитах/гнейсах составили $784 \pm 13{ }^{\circ} \mathrm{C}$ и $3,8 \pm 0,7$ kbar. Bepoятные количественные соотношения различных литотипов в объеме донской серии представляются следующим образом: преобладают амфиболиты и амфибол-биотитовые гнейсы (более 50 \% объема), развитые не повсеместно мраморы и известково-силикатные породы (от 15 до $25 \%$ ), прослои биотитовых гнейсов (около $10 \%$ ), единичные прослои амфиболовых магнетитовых кварцитов и пироксен-магнетитамфиболовых кристаллических сланцев.

5. Мафитовый до среднего химизм, в целом однородный минеральный состав, единые тренды на петрохимических диаграммах амфиболитов и биотитамфиболовых гнейсов позволяют отнести их к исходно вулканогенным и вулканогенно-осадочным образованиям. Полосчатость, неравномерная зернистость с присутствием крупных ксеногенных обломков, малая мощность тел биотитовых гнейсов свидетельствуют в пользу терригенной природы с возможной примесью вулканогенного материала. А накопление толщ донской серии в морском бассейне подтверждается прослоями мраморов и известково-силикатных пород (протолиты - известняки и мергели).

\section{ЛИТЕРАТУРА}

1. Геодинамика восточной окраины Сарматии в палеопротерозое / А. А. Щипанский [и др.] // Геотектоника, 2007. № 1. - C. 43-70.

2. Бердников, М.Д. Раннедокембрийский гранитоидный комплекс юго-востока ВКМ / М. Д. Бердников, С. П. Молотков // Вопросы геологии и металлогении докембрия ВКМ. Воронеж, 1977. - С. 14-20.

3. Епифанов, Б. П. Вопросы стратиграфии докембрия Курско-Воронежской антеклизы / Б. П. Епифанов // Материалы по геологии и полезным ископаемым центральных районов Европейской части СССР, вып. 2. Курская магнитная аномалия. Калужское книжное изд-во. - 1959. - С. 28-52.

4. Геология, гидрогеология, железные руды бассейна Курской магнитной аномалии / В. Д. Полищук [и др.] // Кн. 1. Докембрий. - М. - 1970. - Т. I. - 436 с.
5. Лебедев, И. П. К вопросу о геологической природе глубинных неоднородностей земной коры Воронежского кристаллического массива и истории их формирования в раннем докембрии / И. П. Лебедев // Вопросы теории и практики геологической интерпретации гравитационных, магнитных и электрических полей. Труды международной конференции, Воронеж, 1998. - С. 308-314.

6. Терентьев, P. A. Петрография и геохронология гранитов Лискинского плутона Воронежского кристаллического массива / Р. А. Терентьев // Вестн. Воронеж. гос. ун-та. Сер.: Геология. - 2016. - № 3. - С. 43-52.

7. Формирование континентальной коры Сарматии в архее / С. Б. Лобач-Жученко [и др.] // Геология и геофизика, - 2017. - №12. - С. 1886-1914.

8. Зона сочленения Сарматии и Волго-Уралии: изотопногеохронологическая характеристика супракрустальных пород и гранитоидов / Е. В. Бибикова [и др.] // Стратиграфия. Геол. Корреляция. - 2009. - Т. 17. - № 6. - С. 3-16.

9. Новые данные по радиологическому возрасту гранитоидов Центральной части Курской магнитной аномалии / И. В. Найденков [и др.] // Доклады РАН. - 1996. - Т. 351. - № 6. - C. 802-805.

10. Терентьев, Р. А. Проявление син- и постколлизионных гранитов Лосевской шовной зоны (Воронежский кристаллический массив) / Р. А. Терентьев // Вестн. Воронеж. гос. ун-та. Сер.: Геология. - 2013. - № 2. - С. 70-85.

11. Модель геодинамического развития Воронежского кристаллического массива в раннем докембрии / Н. М. Чернышов [и др.] // Геотектоника, 1997. - № 3. - С. 21-30. 12. Египко, О.И. Некоторые минералого-петрографические и геохимические особенности докембрийских гранитоидов юго-восточной части Воронежского кристаллического массива: дисс. ... канд. геол.-минерал. наук / О. И. Египко. Воронеж: Изд-во Воронеж. гос. ун-та. - 1971. - 367 с.

13. Гранитоиды Воронежского кристаллического массива / О. И. Египко [и др.] // Геология, петрология и металлогения кристаллических образований Восточно-Европейской платформы. Т. II. М., - 1976. - С. 47-54.

14. Терентьев, Р. А. Минеральная термобарометрия и геохимия палеопротерозойских магнезиально-калиевых гранитоидов Павловского плутона, Восточно-Европейский кратон / Р. А. Терентьев, К. А. Савко // Вестн. Воронеж. гос. унта. Сер.: Геология. - 2017. - № 3. - С. 34-45.

15. Скрябин, В. Ю. Природа структурно-вещественной неоднородности гипабиссальных гранитных интрузий (на примере Лискинского массива): дис. ... канд. геол.-минер. наук / В. Ю. Скрябин. - 1988. - 258 с.

16. Горбунов, С. И. Основные черты стратиграфии и магматизма Воронежского кристаллического массива / С. И. Горбунов, Ю. С. Зайцев, Н. М. Чернышов // Сов. геология, 1969. - № 10. - С. 8-25.

17. Корреляционная схема стратиграфии и магматизма раннего докембрия Воронежского кристаллического массива / Б. М. Петров [и др.]. МПР РФ, Центргео, - 1998.

18. Савко, К. A. Петрология форстерит-клиногумитовых мраморов Воронежского кристаллического массива / К. А. Савко, В. Ю. Скрябин // Геология и геофизика - 1999. - Т. 40. - № 4. - C. 592.

19. Bogdanova, S. V. Segments of the East European Craton / S. V. Bogdanova // In Gee, D. G., and Beckholmen, M., (eds.) EUROPROBE in Jablonna 1991: Polish Academy of Sciences, Publications of the Institute of Geophysics, 1993. - V. A-20. P. 33-38.

20. Terentiev, $R$. A. Paleoproterozoic evolution of the arc-backarc system in the East Sarmatian Orogen (East European Craton): zircon SHRIMP geochronology and geochemistry of the 
Losevo volcanic suite / R. A. Terentiev, K. A. Savko, M. Santosh // Am. J. Sci. - 2017. - V. 317(5). - P. 707-753.

21. The Early Precambrian metamorphic events in Eastern Sarmatia / K. A. [et al.] // Precam. Research. - 2018. - V. 311. - P. 1- 23

22. Paleoproterozoic granitoids of the Losevo terrane, East European Craton: age, magma source and tectonic implications / R. A. Terentiev [et al.] // Precam. Research. - 2016. - V. 287. - P. 48-72.

23. Igneous Rocks. A Classification and Glossary of Terms. Recommendations of the International Union of Geological Sciences Subcommission on the Systematics of Igneous Rocks, 2nd ed. / R. W. Le Maitre (ed.) / Cambridge, New York, Melbourne: Cambridge University Press. Geol. Mag. - 2002. V. $140 .-367$ p.

24. Nomenclature of pyroxenes / N. Morimoto [et al.] // Am. Mineral. - 1988. - V. 73. - P. 1123-1133.

25. Nomenclature of amphiboles: report of the Subcommittee on Amphiboles of the International Mineralogical Association, Commission on New Minerals and Mineral names / B. E. Leake [et al.] // Can. Mineral. - 1997. - V. 35. - P. 219-246.

26. Foster, M. D. Interpretation of the Composition of Trioctahedral Micas / M. D. Foster // U.S.G.S. Prof. Paper. - 1960. - V. 354B. - P. 1-49.

27. Deer, W. A. An introduction to the rock forming minerals (second edition) / W. A. Deer, R. A. Howie, J. Zussman // Essex: Longman Scientific and Technical, New York: Wiley, 1992. $-696 \mathrm{p}$.

28. Winchester, J. A. Geochemical magma type discrimination: application to altered and metamorphosed igneous rock / J. A.

\section{Воронежский государственный университет}

Терентьев Роман Анатольевич, ведущий научный сотрудник НИИ Геологии ВГУ, кандидат геолого-

минералогических наук

E-mail: terentiev@geol.vsu.ru

Тел.: 8 (473) 222-73-63
Winchester, P. A. Floyd // Earth Plan. Sci. Letters. - 1986. V.28. - P. 459-469.

29. Classification of Altered Volcanic Island Arc Rocks using Immobile Trace Elements: Development of the Th-Co Discrimination Diagram / A. R. Hastie [et al.] // J. Petrol. - 2007. - V. 48. - P 2341-2357.

30. Ewart, A. The mineralogy and petrology of Tertiary-Recent orogenic volcanic rocks: with special reference to the andesiticbasaltic compositional range / A. Ewart // In: Thorp, R.S. (ed.) Andesites: Orogenic Andesites and Related Rocks, John Wiley and Sons, New York. - 1982. - P. 25-95.

31. Irvine, T. N. A guide to the chemical classification of the common volcanic rocks / T. N. Irvine, W. R. A. Baragar // Can. J. Earth Sci. - 1971. - V. 8. - P. 523-548.

32. A geochemical classification for granitic rocks / B. R. Frost [et al.] // J. Petrol. - 2001. - V. 42. - P. 2033-2048.

33. Бердников, М. Д. Петрология субщелочных гранитов и граносиенитов Павловского массива: автореф. дис. ... канд. геол.-мин. наук / М. Д. Бердников. - Новочеркасск. - 1971. $20 \mathrm{c}$.

34. Harrison, T. M. The behaviour of apatite during crustal anatexis: equilibrium and kinetic considerations / T. M. Harrison, E.B. Watson // Geochim. Cosmochim. Acta - 1984. - V. 48. P. 1467-1477.

35. Anderson, J. L. The effects of temperature and $\mathrm{fO} 2$ on the Al-in-hornblende barometer / J. L. Anderson, D. R. Smith // Am. Mineral. - 1995. - V. 80. - P. 549-559.

36. Hammarstrom J. M. Aluminum in hornblende: An empirical igneous geobarometer / J. M. Hammarstrom, E. Zen // Am. Mineral. - 1986. - V. 71. - P. 1297-1313.

\section{Voronezh State University}

Terentiev R. A., leading researcher of Scientific Research Institute of Geology of the VSU, Candidate of Geological and Mineralogical Sciences

E-mail:terentiev@geol.vsu.ru

Tel.: 8 (473) 222-73-63 